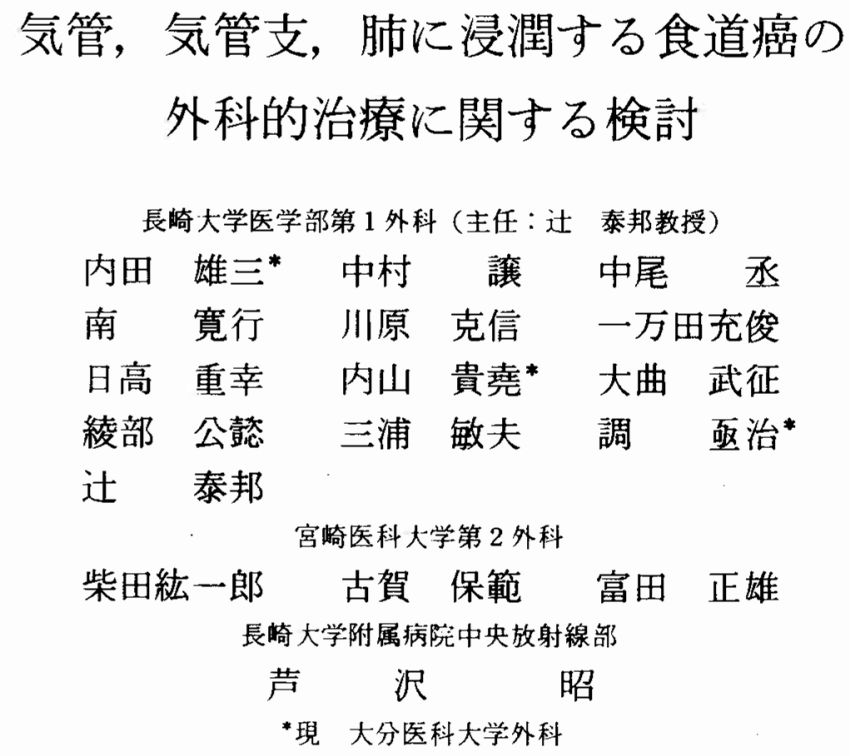

\title{
CLINICAL AND PATHOLOGICAL STUDIES OF CARCINOMA OF THE ESOPHAGUS INVOLVING THE TRACHEA, BRONCHUS, AND LUNG
}

Yuzo UCHIDA, Yoshitaka UCHIYAMA and Joji SHIRABE

Department of Surgery, Oita Medical College

Yuzuru NAKAMURA, Susumu NAKAO, Hiroyuki MINAMI, Katsunobu KAWAHARA, Mutsutoshi ICHIMANDA, Shigeyuki HIDAKA, Takeyuki OHMAGARI, Hiroyoshi AYABE, Toshio MIURA and Yasukuni TSUJI 1st Department of Surgery, Nagasaki University School of Medicine Koichiro SHIBATA, Yasunori KOGA and Masao TOMITA 2nd Department of Surgery, Miyazaki Medical College Akira ASHIZAWA

Department of Radiology, Nagasaki University School of Medicine

原発巣が切除された食道癌症例58例のうち $A_{3}$ 症例は24例であり，これらの症例について臨床的なら びに病理学的に検討し, 気管, 気管支, 肺浸潤例の外科的治療について検討した. $\mathrm{A}_{3}$ 症例24例の5ち $\mathrm{a}_{3}$ 症例は 16 例 $(66.7 \%)$ であり，気管，気管支浸潤例は5 例，肺浸潤例は 5 例であった。気管，気管支浸潤 例のうち, 食道気道㾇を形成した 2 例は術前照射療法なしに合併切除を施行したが 4 カ月以内に死亡し た. 食道気道㾇を形成していない症例住しては浸潤部位を削りとるようにして切除が行われた。肺浸潤 例では 5 例中 4 例に肺部分切除が行われ，1 例では例離が行われた。術後 4 例に肺転移がみられたが，い ずれも浸潤側肺であった. 肺浸潤例に此較し, 気管, 気管支浸潤例の方が頝部リンパ節転移の傾向が大で あった。照射例の中には $A_{3}=a_{0-2}$ の症例があり，浸潤部位の癌組織が消失したと思われる症例もある。 以上の成績より次のように結論する. (1) 肺浸润例に 対しては肺部分切除が積極的に行われる. (2) 気 
管，気管支浸潤例で食道気道瘦を形成していない症例では限局型 $A_{3} \cdot N_{0-1}$ 症例においてのみ合併切除が 考虑され得る。それ以外の症例では浸潤部位をでさるだけ含めて切除し，遺残癌組織には照射を主とした 後療法が行われる.切除不能例拉よび瘦孔形成例では，先ず By-pass 手術を優先し，根治照射を行らのが よい.ただし，Ce 症例は例外である。

索引用語：食道癌，気管・気管支・肺浸潤例

\section{I. はじめに}

近年食道癌の診断技術は向上してきたが，外科を訪水 る食道癌症例の多くは依然として相当な進行癌である. 消化管癌の手術では, 根治性を期待した徹底的な廍清と 最大限の機能温存といら矛盾した二面が要求されるが, 食道癌手術後の成績もまた癌の根治性と術後合併症の防 止によって向上し得る.したがって, 手術時所見の適確 な把握に基づいて，影清の程度と再建術式の選択関す る正しい決断が要求される.

食道癌の術後再発を左右する因子としては, 臟器転移 の有無, ソンパ節転移の程度, 外膜浸潤の程度などがあ げられる、とくに，隣接臟器への浸潤の程度は，合併切 除の適応を決定する因子として，極めて重要な意義を有 する. 本稿ではとくに気管, 気管支, 肺への浸潤例につ いて, 自験例の臨床病理学的検討ならびに手術と術後経 過の反省に文献的考察を加えて報告する.

\section{II. 検索対象と方法}

昭和 44 年から 53 年まで 10 年間の長崎大学医学部第 1 外 科に怙ける食道癌患者の入院数は105例であり，そのう ら原発巣が切除されたものは58例である. 残りの非切除 例47例に行わ机た処置は, By-pass 手術 4 例, 栄養小腸 瘻造設術 9 例, 試験開腹術 1 例, 非観血的処置33例であ る. 原発巣を切除した58例の年齢構成は, 30 歳台 1 例, 40 歳台 8 例, 50 歳台 17 例，60歳台 21 例， 70 歳台 11 例，最 年少者は38歳, 最高路者は74歳で平均 60.4 藏である. 男 女比は 9：1で男性が多い. 主な占居部位別にみると $\mathrm{Ce} 1$ 例, $\mathrm{Iu} 7$ 例, Im 31例, $\mathrm{Ei} 16$ 例, $\mathrm{EaC}$ (扁平上 皮癌） 3 例である.

臨床所見ならびに切除標本の病理学的所見の記載方法

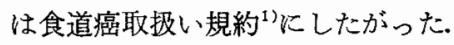

\section{III. 成}

原発巣を切除できた58例のうち $\mathrm{A}_{3}$ 症例は24例であ り, その被浸潤藏器 (浸潤相手臟器) は大動脈または大 動脈々その他の藏器との組合せが最も多く、気管または 気管支への浸潤例は 5 例, 肺への浸潤例は 5 例である.
$\mathrm{A}_{3}$ 症例のうち術前照射療法をらけたものは16例で, 組織学的検索の結果 $a_{3}$ と判定されたものは16例であ る. 術前照射を行った $\mathrm{A}_{3}$ 症例16例中, $\mathrm{a}_{0 \sim 2}$ と判定さ れたものは 6 例である.

\section{A. 気管, 気管支漫润例}

手術時の肉眼的所見で，食道癌が気管または気管支へ 浸潤していると診断されたものは 5 例であり，年龄は 54 歳から66歳, 男性が 4 例, 女性が 1 例である. 癌の主 な占居部位は, Ce+Iu 1 例, Iu 1 例, Iu + Im 2 例, Im 1 例である(表 1 ).

1) 症状と検查所見

症例（1）から（4）までの4例の主訴は dysphagia であり，症例（1)ではさらに血痰がみられた，症例 (5) の主訴は咳濑と血痰であり, その胸部X線（単純撮影） 所見からも，初診時汇は肺癌が疑われた，食道造影所見 は, 症例（1)から（4)までがらせん型で, 症例 5 は鋸歯 型であり，陰影欠損部の長さは $6.0 \mathrm{~cm}$ から $10.0 \mathrm{~cm}$ で あった。さらに, 症例 (2)，(3)，(5)の3例では陰影欠 損部位に造影剂の突出像が双られたが，気管または気管 支への流入は認められなかった. 食道ファイバースコー プの所見は, 症例 (1)では食道入口部の狭窄があり, ス コープの插入が困難であった．症例 (2)，(3)，(4)の 3 例では全周性の潰瘍形成がみられた。症例（5)では，隆 起性の病变または外側からの圧迫による膨隆として観察 されている. 症例 (2)，(3)，(4)では内視鏡下に生検が 施行され，扁平上皮癌の診断を得た。症例（1）には喉頭 鏡を, 症例 (3)拉よび（5）には気管支鏡を施行し，気 管，気管支の粘膜面を観察した。症例（3）では気管なら びに左主気管支膜様部の膨隆がみられ，症例 (5)では右 中幹気管支の閉塞像が認められた。ささらに, 症例 (5)で は気管支造影で右中幹気管支内側に陰影欠損像があり， $\mathrm{rB}^{4+5}$ は造影されなかった. 肺動脈造影でも $\mathrm{PA}^{5}$ は淡 く，末梢は狭小化していた，本症例では喀痰の smear test で癌細胞を認め, 扁平上皮癌の診断を得た（表 1 ）. 症例 (1)怙よび (5)以は術前照射療法を施行せず, 症 
表 1 食道癌の気管・気管支浸潤例（症状と検査所見）

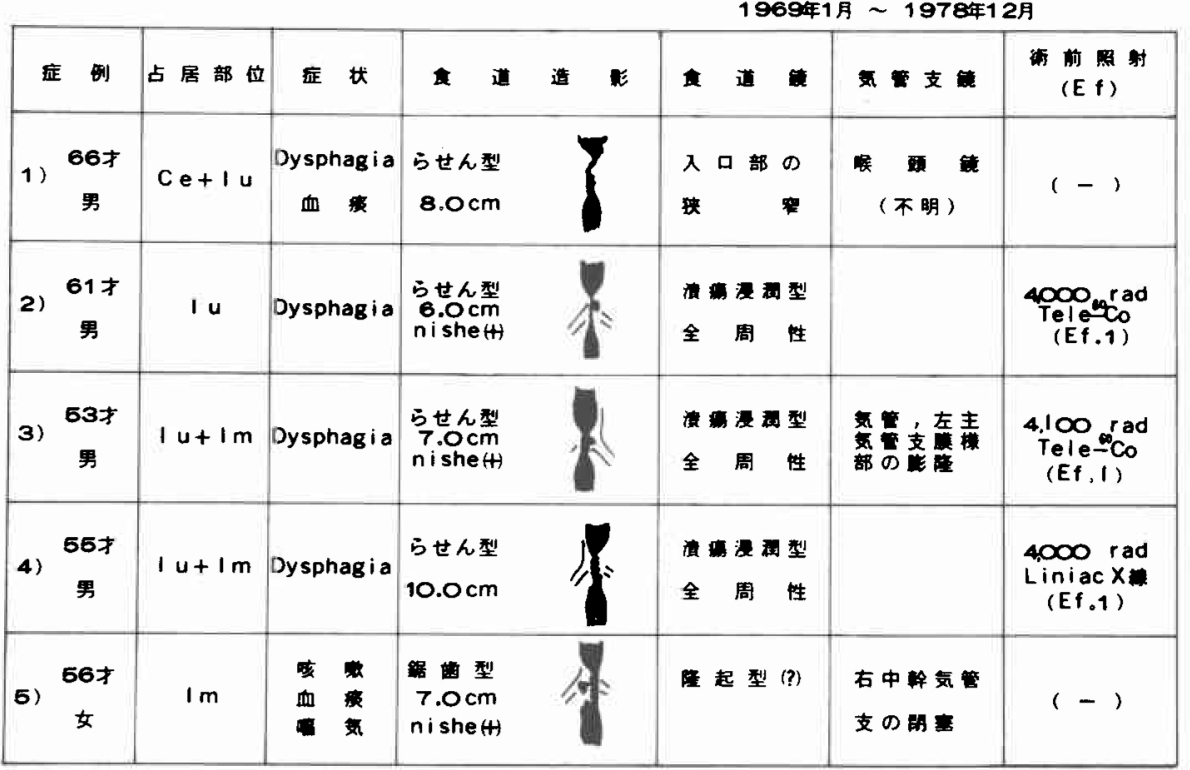

表 2 食道癌の気管・気管支漫潤例（手術時所見と術後経過）

\begin{tabular}{|c|c|c|c|c|c|c|c|c|}
\hline 应 & 占居部位 & 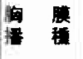 & 窝眼的リンパ & 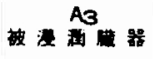 & $\underset{\omega}{\text { 気管，気管支 }}$ & 点道再越 & 再 & $\begin{array}{l}\text { 生存期間 } \\
\text { (死因) }\end{array}$ \\
\hline 1) $\begin{array}{c}66 t \\
\text { 男 }\end{array}$ & $\mathrm{Ce}+1 \mathrm{u}$ & $(-)$ & & & 切 & 施行せず & 不 & $\begin{array}{c}\text { 13日 } \\
\text { (心讳不全) }\end{array}$ \\
\hline 2) $\begin{array}{c}61 \mathrm{f} \\
\text { 男 }\end{array}$ & lu & $(-)$ & $\begin{array}{l}101,102 \\
104,107 \\
\mathrm{~N}_{4}\end{array}$ & 娥 & 粦 & 葫行せず & 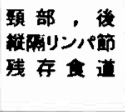 & $\begin{array}{l}3 \text { カ月19日 } \\
\text { (回出血) }\end{array}$ \\
\hline 3) & $I \mathrm{u}+\mathrm{Im}$ & $(-)$ & $\begin{array}{l}106,106 \\
107,108 \\
110 \quad \mathrm{~N}_{2}\end{array}$ & 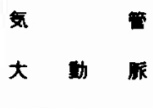 & $\begin{array}{l}\text { 制 離 } \\
\text { (一部造残 ? ) }\end{array}$ & (2 期分割) & 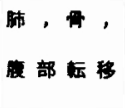 & 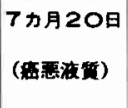 \\
\hline 4) $\begin{array}{c}\text { 55才 } \\
\text { 男. }\end{array}$ & $1 u+I m$ & $(-)$ & $\begin{array}{l}105,106 \\
107,100 \\
110 \quad \mathrm{~N}_{3}\end{array}$ & 右主果支 & 粗 & (2期分割) & 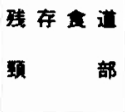 & $\begin{array}{l}\text { 3カ月17日 } \\
\text { (肺 炎) }\end{array}$ \\
\hline 5) $\begin{array}{c}\text { 56 J } \\
\text { 女 }\end{array}$ & In & $(-)$ & $\begin{array}{l}1,2,3,8 \\
9,107,108 \\
109,110 \\
\mathrm{~N}_{4}\end{array}$ & 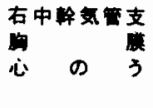 & 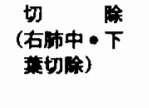 & (2期分割) & 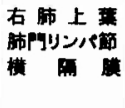 & 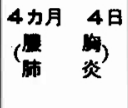 \\
\hline
\end{tabular}

例 (2)は Tele- ${ }^{60} \mathrm{Co} .4,000 \mathrm{rad}$, 症例 (3)は Tele- ${ }^{60} \mathrm{Co}$. 4,100 rad, 症例 (4)は Linac X線 4,000 rad の照射療法 を施行した（表 1 ).

2) 手術時所見
症例（1）から（5）の全例で右側開胸下に胸部食道を切 除し, 症例 (1)ではさらに頝部横切開下に頝部食道・気 管・喉頭の合併切除が行われた（表 2 ）.

全例で胸膜への播種性転移および肺転移は認められな 
かった.

肉眼的リンパ節転移は, 症例 (3)が $\mathrm{N}_{2}$, 症例 (4)が $\mathrm{N}_{3}$, 症例 (2)，(5)が $\mathrm{N}_{4}$ であり，4 例とも107リンパ節 への転移が疑われた，占居部位別にはIuにおよ゙症例 では104または105リンパ節への転移が，Im に拉上ぶ症 例では110リンパ節への転移が疑われた， 4 例中 2 例で 109 リンパ節への転移が疑われ，廓清された，組織学的診

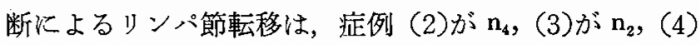
が $\mathrm{n}_{2}$ ，(5)が $\mathrm{n}_{4}$ である.すなわち $\mathrm{N}=\mathrm{n}$ が 3 例， N>n が 1 例，不明が 1 例である.

$\mathrm{A}_{3}$ の被浸潤蔵器は, 気管が 3 , 右主気管支が 1 , 右 中幹気管支が 1 例であった。これらの症例では，この他 に大動脈，胸膜，心のうなどへの癌浸潤がみられた。こ れらの症例で被浸潤臓器である気管または気管支に対す る処置は, 症例 (1)では気管の合併切除, 症例 (5)では 右中幹気管支を含屯右肺中・下莱切除が行われ，他の 3 例では鋭的に，癌組織をできるだけ食道側につけるよう にして食道切除が行われ，必要に応じて気管壁外側を削

写真 1, 気管浸潤例 (症例 1 ) の切除標本. 食道な らびに筧管の粘膜面て，瘦孔がみられる。

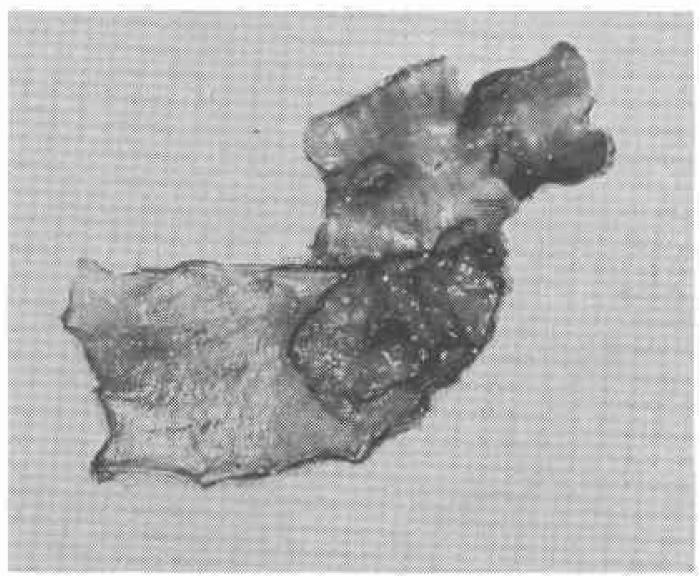

りとるようにして追加切除を行った。癌浸潤部をみる と, 症例（1）では食道気管瘦の形成が確認され（写真 1 ）, 症例（5）では右中幹気管支の主として膜様部を中 心明かな癌浸潤がみられ（写真 2)，小さな食道気管 支瘻の存在も疑われた。な症例（5)の切除された右 中幹気管支内面には腫瘤形成があり，内腔は閉塞されて いた（写真 3 ).

3) 病理学的所見

切除された標本の病理学的所見をるると（表 3)，食
写真 2. 気管支浸潤例（症例 5 ) の切除標本. 右中 幹気管支の膜様部に癌浸潤がみられる(矢印).

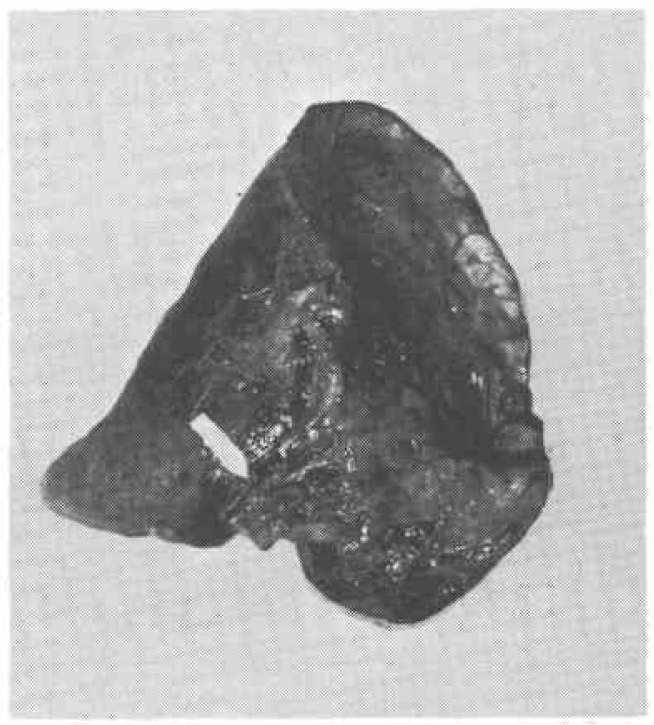

写真 3 . 気管支浸濞例（症例 5 ）の切除標本. 右中 幹気管支の内腔は，癌浸潤により閉塞している。

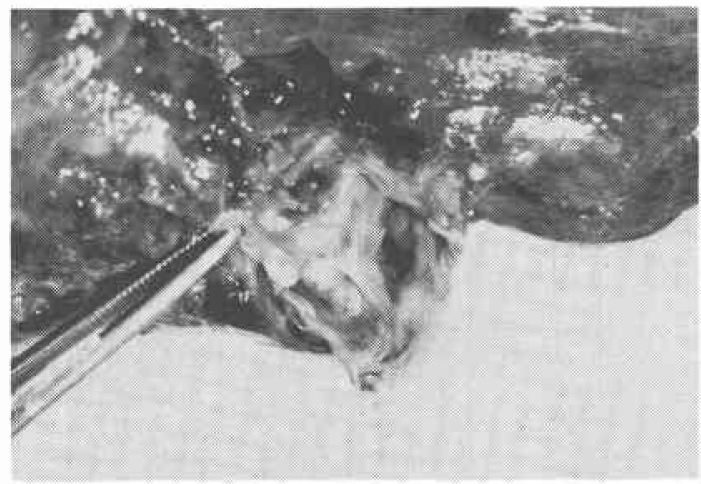

道の原発巣はすべて潰煌型または R-潰瘍形で，大きさ は $6.5 \times 4.5 \mathrm{~cm}$ から $2.5 \times 2.3 \mathrm{~cm}$ 大であった（写真 1 ，

$4)$. 組織型は中分化型扁平上皮癌が 1 例, 低分化型扁 平上皮癌が 4 例で, 術前照射療法を受けた 3 例の原発栄 の組織学的効果は 3 例とも Ef 1 であった. 樑達度は $a_{3}$ が 2 例，R-a $\mathrm{a}_{3} 2$ 例，R-a $\mathbf{a}_{2}$ が 1 例であった. 局所に拈け る癌浸潤增殖の椂式は，INF- $\beta$ が 2 例，INF- $\gamma$ が 3 例 であり，術前照射例の 3 例はすべて INF- $\gamma$ であった。 リンパ管侵襲の像は 5 例全例に認められた。

気管，気管支壁への浸潤部位をみると，症例（2)では 廄痕組織のみで, 追加切除した組織内にも癌組織はみら れなかった. 症例（3)，(4)では癌組織がみられ，とく 
表 3. 食道癌の気管・気管支漫潤例（病理学的所見）

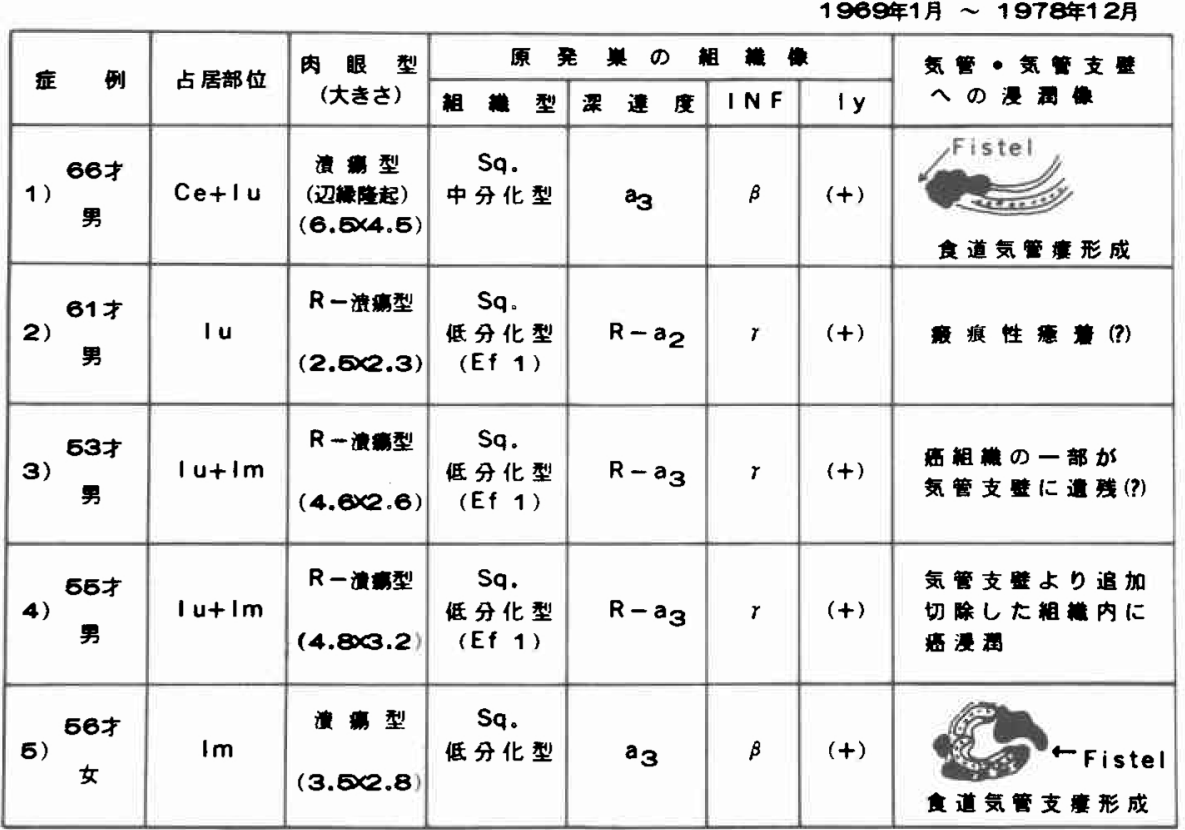

表 4. 食道癌の肺浸潤例（症状および検查・手術・病理所見）

\begin{tabular}{|c|c|c|c|c|c|c|c|c|c|c|}
\hline 症 例 & 占居部位 & 症 状 & 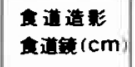 & 術前秚时 & ${ }^{A_{3}}$ & $\begin{array}{l}N \\
\text { pl }\end{array}$ & 粗灣型 & $\begin{array}{l}\text { INF } \\
\text { Iy }\end{array}$ & $\frac{a_{3}}{z^{3}}$ & $\begin{array}{l}\text { 生存期䦭 } \\
\text { 再無 (死因) }\end{array}$ \\
\hline 1) $\begin{array}{c}71 才 \\
\text { 男 }\end{array}$ & $1 m+1 u$ & $\begin{array}{c}\text { Dysphagia } \\
\text { 背部雨 }\end{array}$ & 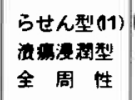 & $\begin{array}{l}\text { Liniac Xit } \\
4,000 \mathrm{rad}\end{array}$ & $\begin{array}{l}\text { 古肺 } S^{6} \text { (切除) } \\
\text { 问腃 }\end{array}$ & $\begin{array}{l}N_{2} \\
(-)\end{array}$ & $\begin{array}{c}\text { Sq } \\
\text { 中出化 } \\
\text { (Ef } 2 \text { 2) }\end{array}$ & $\begin{array}{l}r \\
H\end{array}$ & $\begin{array}{c}R-a_{2} \\
\text { Fistel 形成 }\end{array}$ & 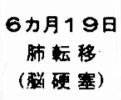 \\
\hline 2) $\begin{array}{c}72 才 \\
\text { 男 }\end{array}$ & $1 m+1 u$ & $\begin{array}{c}\text { Dysphagia } \\
\text { 部第 }\end{array}$ & 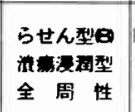 & $\begin{array}{l}\text { Liniac X } \\
4000 \mathrm{rad}\end{array}$ & 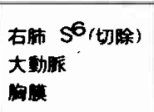 & $\begin{array}{l}\mathrm{N}_{4}^{*} \\
(-)\end{array}$ & $\begin{array}{c}\text { Sq } \\
\text { 中分化 } \\
\text { (Ef 1) }\end{array}$ & $\begin{array}{l}\beta \\
H\end{array}$ & 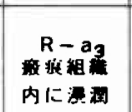 & 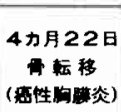 \\
\hline 3) $\begin{array}{c}65 才 \\
女\end{array}$ & Im & Dysphagia & 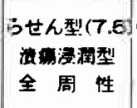 & $\left\{\begin{array}{l}\text { iniac } x \text { : } \\
\text { 1,200 rad } \\
\text { it形成? }\end{array}\right.$ & $\begin{array}{l}\text { 右肺 } 5^{6} \text { (切除) } \\
\text { 心のう (切除) } \\
\text { 胸㬴 }\end{array}$ & $\begin{array}{l}\mathrm{N}_{2} \\
(-)\end{array}$ & $\begin{array}{c}\text { Sq } \\
\text { 离分化 } \\
(E f \quad 1)\end{array}$ & $\alpha$ & 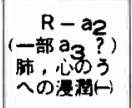 & $\begin{array}{l}\text { 声 接 死 } \\
\text { (出血傾向) }\end{array}$ \\
\hline 4) $\begin{array}{c}58 t \\
\text { 女 }\end{array}$ & $|m+E|$ & Dysphag i a & 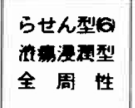 & $\begin{array}{l}\text { Tele }{ }^{\text {COCo. }} \text {. } \\
4,000 \mathrm{rad}\end{array}$ & 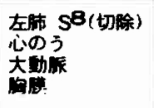 & $\begin{array}{l}N_{1} \\
(-)\end{array}$ & $\begin{array}{c}\mathrm{Sq} \\
\text { 低分化 } \\
(\mathrm{Ef}, 1)\end{array}$ & $\begin{array}{c}r \\
H+1\end{array}$ & 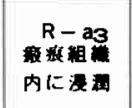 & 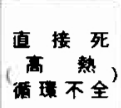 \\
\hline 5) $\begin{array}{c}567 \\
\text { 男 }\end{array}$ & E i & $\begin{array}{c}\text { Dysphagia } \\
\text { 部荡 }\end{array}$ & & 施行せず & $\begin{array}{l}\text { 右肺 } S^{7} \text { (制離) } \\
\text { 大動属 }\end{array}$ & $\begin{array}{l}\mathrm{N}_{4}^{*} \\
(-)\end{array}$ & $\begin{array}{c}\text { Sq } \\
\text { 低分化 } \\
(-)\end{array}$ & $\begin{array}{l}\beta \\
H\end{array}$ & 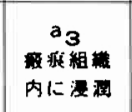 & 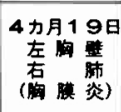 \\
\hline
\end{tabular}


写真 4. 気管支浸潤例（症例 5）の切除標本，食道 癌，潰瘄型.

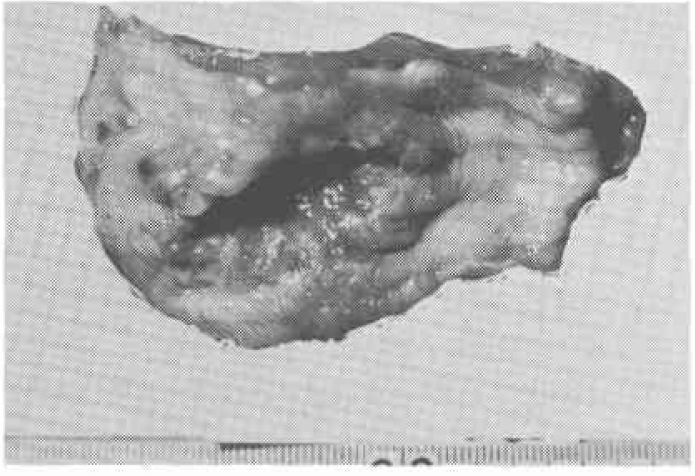

写真 5.気管浸潤例（症例 1) の組織像。上段矢印 は瘦孔を示す。下段は震孔壁の癌浸潤像，中分化 型俩平上皮癌。

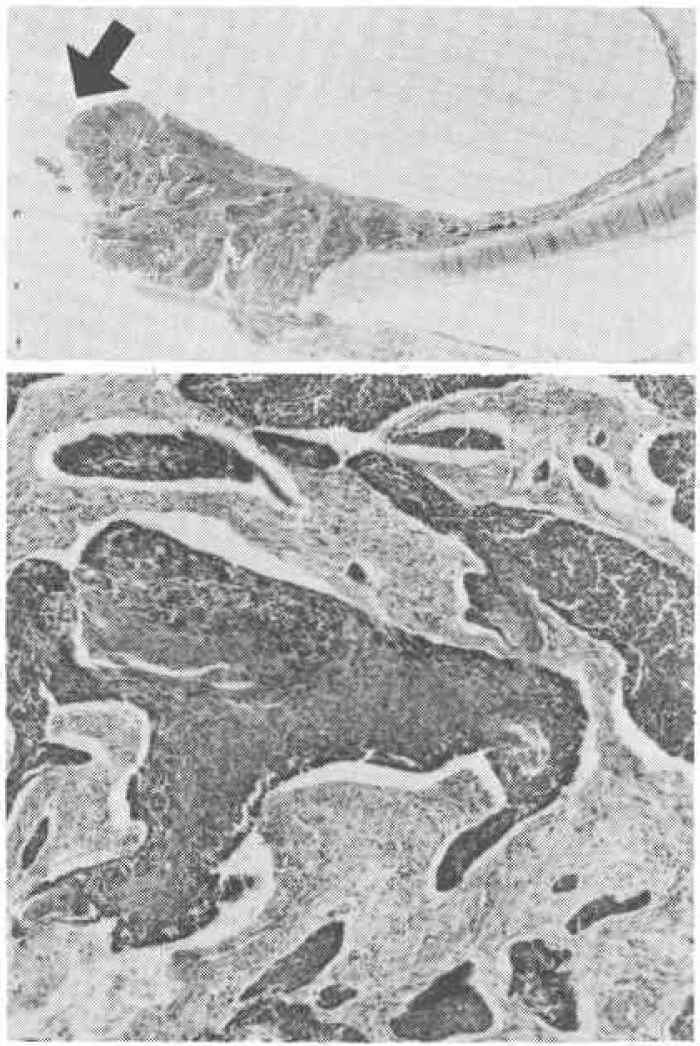

に症例（3）では気管支壁の一部に癌組織の遺残が疑われ る. 気管の合併切除を行った症例（1）では，気管膜様部 に明らかな瘦孔形成がみられ，その㾞孔壁は癌組織から なっている(写真 5 ). この部位では扁平上皮癌の組織
写真 6 . 気管支浸潤例（症例 5 ）の浸潤部位。矢印 は癌浸潤が気管支膜様部を穿破して気管支腔内へ 突出している部位を示す、瘦孔壁ですある。左上 段はその組織像。

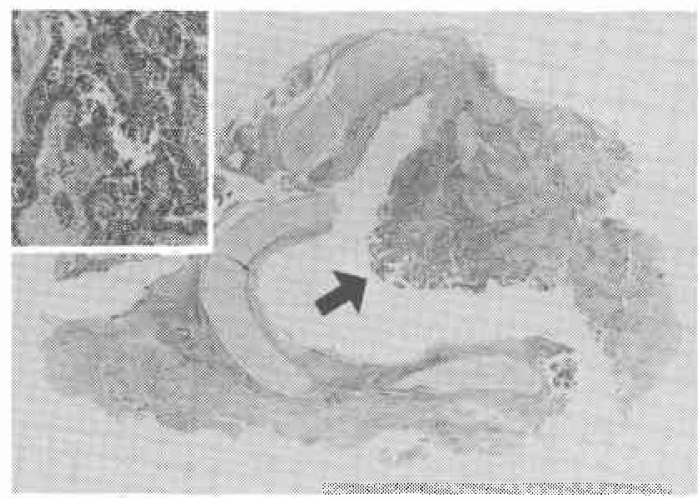

写真 7.気管支浸潤例（症例 5) の原発巣の組織像. 低分化型扁平上皮癌. 右朹内は周辺粘膜との移行 部を示す。

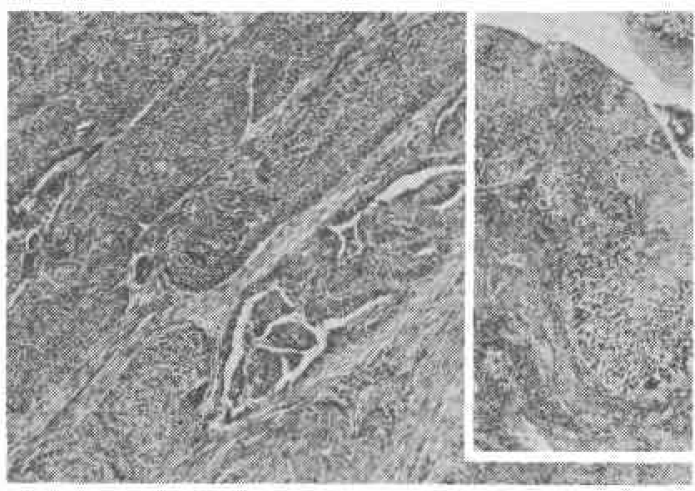

が気管壁を破壊して気管内腔に露出している．症例（5） では, 癌組織が右中幹気管支膜様部の壁を浸潤破壞して 腫瘤状に気管支内曌に突出している（写真6）。この部 位では低分化型扁平上皮癌の浸潤像と, 一部乳頭状に増 殖している像とがみられる。この症例は臨床経過の初期 において原発性肺癌が疑われたこともあるので，とくに 入念に食道原発巣を精査したが，原発巣においても低分 化型扁平上皮癌の浸潤像に混って乳頭状の增殖像もみら れまた癌巣辺縁部の粘膜上皮層には，粘膜上皮内伸展 (ie) の像, dysplasia の像を混えたいわゆる移行像があ り（写杰 7), 食道原発之診断された。

4) 術後経過

これらの症例の術後経過をみると（図表 2), 症例 (1) は術後13日目に心肺不全のため死亡している. 症例（2） 
は䅡部および縱隔リンパ節に転移を来し,さらに頝部の 口側残存食道壁に転移巣を認めるようになったので, Linac 電子線の照射を行ったが， 7,200 rad の時点で突 然大量の胃出血を来して死亡した，症例（3)は右肺上 葉, 右上腕骨, 右肩胛骨, 左第 2 助骨に転移を来し, さ らに腹部に腫瘤を触知するようになり, 腹水の貯溜も出 現した. ブレオマイシン (255mg) の投与を行ったが, 癌性悪液質の症状を呈して, 術後 7 力月 20 日目に死亡し た. 症例 (4)は頝部残存食道壁と䫋部リンパ節に転移を 来し, 肺炎を併発して死亡した. 症例（5）食道と右中 幹気管支ならびに右肺中下葉の合併切除術後も喀痰中に 癌細胞が認められた. 剖検時に右肺上葉, 肺門リンパ 節，右横隔膜に転移が認められた. 術後生存期間は13日 から 7 カ月 20 日であり, 直死の 1 例（症例 (1))を除い て4例に再発がみられた。

\section{B. 肺浸潤例}

手術時の肉眼的所見で食道癌が肺へ浸潤していると診 断されたものは 5 例であり, 年齢は56歳から71歳, 男性 3 例, 女性が 2 例である. 癌の占居部位は Im+Iu 2, $\operatorname{Im} 1, \operatorname{Im}+\mathrm{Ei} 1, \mathrm{Ei}$ が1例である（表 4 ）.

1) 症状と検查所見

主な症状として，5例とも dysphagia を訴えており， 4 例に背部痛交たは胸部痛がみられた。食道造影所見 は，4例がらせん型で ( 1 例は資料なし)，陰影欠損の 長さは $6 \mathrm{~cm}$ から $11 \mathrm{~cm}$ である.内視鏡所見は 4 例が全 周性の潰瘍浸潤型であった，症例（5）の食道造影ならび に内視鏡所見の資料が不明であった。

症例 (1)，(2)，(3)，(4)に術前照射療法を施行した. 3 例に Linac X線，1 例に Tele- ${ }^{60} \mathrm{Co}$ を, 4,000 rad を 目標に照射したが，症例（3)は照射期間中に瘦孔を形成 したと判断されたので 1,200 rad で中止した. 症例（5） には術前照射療法を施行しなかった。

\section{2) 手術時所見}

症例（1)，(2)，(3)は右開胸下に, 症例（4)，(5)は 左開胸下に切除を施行した (表 4 )。. $A_{3}$ の被漫潤藏器 は, 肺の他に胸膜, 心のう, 大動脈などであり, 肺への 浸潤部位は開胸側肺の $\mathrm{S}^{6}$ か 3 例, $\mathrm{S}^{8}$ が 1 例, 対側の $\mathrm{S}^{7}$ が 1 例であった. 開胸側肺に浸潤していたものでは 肺の部分切除が行われ，対側肺に浸潤していた症例で は，浸潤部位をでさるだけ食道側につけるようにして鋭 的に剥離された， 5 例之も胸膜への播種性転移は認めら れなかった。

肉眼的シンパ筋転移の 程度は, 症例 (4)が $\mathrm{N}_{1}$, 症例
(1)，(3)が $\mathrm{N}_{2}$, 症例 (2)，(5)が $\mathrm{N}_{4}$ であったが, $\mathrm{N}_{4}$ 症 例の 2 例では, 腹腔内リンパ節転移 (7), (9))が疑われ たために $\mathrm{N}_{4}$ となったるのである. 組織学的 リンパ節 転移は, 症例 (1)が $n_{0},(2)$ が $n_{2},(3)$ か $n_{1}$, (4)が $n_{1}$, (5)が $\mathrm{n}_{3}$ であり, 肉眼的判定と組織学的判定の関係は $\mathrm{N}=\mathrm{n} 1$ 例， $\mathrm{N}>\mathrm{n} 4$ 例であった. とくに $\mathrm{N}_{4}$ の2 例で は, 腹腔内リンパ節転移を疑って $\mathrm{N}_{4}$ とし, 廓清された リンパ節には転移はなく, $\mathrm{n}_{3}, \mathrm{n}_{2}$ であった。

3) 病理学的所見

原発巣の組織型はすべて扁平上皮癌であり, 高分化型 1 例, 中分化型 2 例, 低分化型 2 例であり, 術前照射の 組織学的効果は Ef 1 が 3 例, Ef 2 が 1 例であった（表 4 ). 局所における浸潤増殖の様式は, INF- $\alpha$ が 1 例, INF- $\beta$ が 2 例, INF- $\gamma$ が 2 例であった.リンパ管侵襲 の像は全例に認められた， $A_{3}$ 部位の組織学的所見は, 4 例で癌組織の浸潤像があり, 照射期間中に瘦孔を形成 したと思われた症例（3）では，その瘦孔壁の症痕組織中 には癌組織を認めなかったが、瘾着部の洀痕組織中に浸 潤がみられた. R-a 3 の 4 例の共通点は, 肺との窑着部 の洀痕組織中に癌浸潤がみられたが，通常の肺組織への 浸潤像はみられなかったことである。

\section{4）術後経過}

直接死が 2 例, 約 4 力月生存例 2 例, 約 6 力月生存例 が 1 例であった（表 4). 症例（1）は術後右肺に転移を 来したが，6カ月19日目に脳硬塞で死亡した. 症例 (2) は骨転移を示し, 癌性胸膜炎で死しした. 症例 (5)は左 側 (開胸側) 胸壁と右側 (浸潤側) 肺に転移を来し, 胸 膜炎で死亡した.

\section{C. 気管, 気管支, 肺漫洞例の術後経過の特街}

気管, 気管支または肺への浸潤例10例の術後経過をみ ると, 全例が 1 年以内に死亡している. 術後肺転移を示 した症例は 4 例であるが， 4 例とも浸潤側の肺への転移 であった.

気管，気管支浸潤例と肺浸潤例の転移傾向の差異は, 前者では暊部リンパ節への転移を来した症例が 2 例みら れたが，後者ではみられなかったことである.

\section{IV. 考 察}

食道癌症例の手術時所見々予後との関係は, 臟器転移 $\left(\mathrm{M}_{1}\right)$ 例や胸膜播種性転移 $\left(\mathrm{Pl}_{1}\right)$ 例で悪いのは当然で あるが， $\mathrm{M}_{0} \cdot \mathrm{Pl}_{0}$ では，その全身状態を考虑しながら， A因子とN因子拈よびその組合せによって切除度ならび に根治度に対する期待が決定される. したがって $\mathrm{A}_{3}$ で 切除不能例もあれば $\mathrm{N}_{3 \sim 4}$ で根治度 $\mathrm{C}_{0}$ の症例 す存在 
する.しかし実際に手術を担当した外科医にとっては， $A_{3} \cdot N_{0 \sim 2}$ 症例に対する合併切除, 括よび $A_{3} \cdot N_{2 \sim 4}$ 症 例に対するリンパ節廓清範囲の決定が重要な問題とな る.

$a_{3}$ 症例について：食道癌切除例の中で $a_{3}$ 症例が占 める頻度は $13 \sim 34 \% \%^{233)}$ と報告されて拈り，教室の症例 では $28.1 \%$ である. 術前および術中の所見から $\mathrm{A}_{3}$ と判 断され，切除標本の組織所見で $\mathrm{a}_{0 \sim 2}$ と診断される症例 も存在 ${ }^{2) 4}$ 寸ることから, 術前照射施行例では, $A_{3}$ 症例 といえども切除を試みる価値があると考える。

$\mathrm{A}_{3}$ 症例の術後経過をその術後 1 年生存率でみると, 切除例 $\left(\mathrm{a}_{3}\right)$ で15 34\% ${ }^{2) 3)}$, 非切除例 で $4.3 \sim 16.7 \%$ と されており，切除例の中です明が癌巣の一部を残さざ るを得なかった症例では11.1〜26.3\% ${ }^{3)}$ である. 切除例 については $A_{3}=a_{3}$ であった症例よりも $A_{3}=a_{0-2}$ であっ た症例の方が 1 年生存率が高い ${ }^{2)} . A_{3}\left(a_{3}\right)$ 症例におけ る浸潤の相手臓器（被浸潤蔵器）は大動脈または大動脈 と他蔵器との組合せが最も多いとする報告 ${ }^{2) 4}$ と, 気管, 気管支, 肺の気道系が多いとする報告 ${ }^{335) 6)}$ とがあるが, いずれにせよ大動脈または気道系への浸潤が最も多く， $\mathrm{A}_{3}$ 症例が非切除または姑息的切除に終る大きな理由に なっている. 教室の症例では，気管，気管支，肺への浸 潤例は切除された $\mathrm{A}_{3}$ 症例の $41.7 \%$ であった。

リンパ節転移について： $A_{3}$ または $a_{3}$ 症例の予後を左 右する因子として，癌巣が完全に除去されたか否かが有 意義であることはすでに述べたが，ての他に，n（一） か n（十）であるかが大きな因子であるとする報告卓11) ああり, $a_{3}$ 症例では $a_{3} \cdot n_{0 \sim 1}$ のみが根治性を期待でき ることを示唆している.

食道のリンパ路については，食道の部位によって 3 群 に大別 ${ }^{73)}$ して論じられる。すなわち, 食道の上 $1 / 3$ 部から のリンパ管は両側の気管傍リンパ節, 深頝部リンパ節に 注ぎ, 中 $1 / 3$ 部からのリンパ管は気管傍リンパ節, 気管前 リンパ節，後綖隔リンパ節に入る.下1/3部からのリン パ管は噴門部リンパ節に注ぐ、さらに，食道壁より出た リンパ管は必ずしも傍食道に一次りンパ節を造らずに, 直接気管系リンパ節あるいは後縱隔リンパ節に注ぎ，あ るいは食道壁に沿った集合リンパ管として上下に走るも のが存在するという特殊性を有する ${ }^{7 / 8)}$.この事実は手

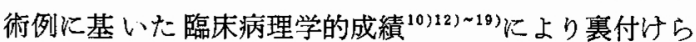
れて扣り，とくに，胸部食道癌に拈ける頝部りンパ節転 移の意義が強調 ${ }^{19) 20) さ れ て い る . ~}$

気管から出るリンパ管を Rouviere は気管前リンパ節
に終る前リンパ集合管と気管傍リンパ節に注ぐ外側リン パ集合管とに分けて ${ }^{7) 8)}$ いる.さらに気管傍りンパ節の 輸出管は大部分が中群に集められ，右側では静脈または 下深頊りンパ節に，左側では大部分が胸管に，一部が下 深䅡リンパ節に注〈゙が ${ }^{788) 9}$ ，一部，上気管気管支りンパ 節より腕頭静脈角リンパ節に注ぐものもある ${ }^{829)}$. した がって, 食道癌の気管・気管支浸潤例におけるリンパ節 転移のルートは, 単に食道壁からの輸出路のルートのみ ならず，気管・気管支壁からの輸出路のルートが併せて 考虑されねばならない，教室の気管・気管支浸潤例のリ ンパ節転移の傾向をみても, 気管, 気管支に浸潤する食 道癌のリンパ行性転移のルートの複雑さとそのリンパ節 廓清の困難さがらかがわれる.

手術時に括けるリンパ節転移の肉眼的判定の適中率に ついて，川口 ${ }^{15}$ は $\mathrm{N}(+)$ と $\mathrm{n}(+)$ の一致率は66\% にすぎいとし，組織学的診断の重要性を強調してい る. 教室の検索例では, $\mathrm{N}=\mathrm{n}$ は63\%で, 残りの37\%は $\mathrm{N}>\mathrm{n}$ であり，とくに $\mathrm{N}_{\mathbf{2} 3}$ の症例の適中率に問題があ るように思われる. したがって，このことは $\mathrm{N}_{2 \sim 3}$ と思 われる症例では $\mathbf{N}>\mathbf{n}$ の可能性むあるので, 状態が許す かぎり，摘出可能と思われるリンパ節はできるだけ多く 摘出する万がよいことを示唆しているように思古る.

気管, 気管支, 肺への浸潤例 : Iu, Im 食道癌の浸潤 相手臓器のうち気道系が占める割合は44〜50\% ${ }^{621) て ゙ あ ~}$ り，教室の症例では $\mathrm{A}_{3}$ 食道癌の $38.5 \%$ に相当する. Garlock $(1951)^{22)}$ の報告では, 被浸潤藏器 が明らかな 症例では気道系への浸潤が切除不能の大きな理由になっ ている，気道系への浸潤例では，大動脈への浸潤の場と 異り, 症例によっては気道の合併切除が可能な症例も存 在するために，合併切除を行うべきか，姑息的切除にと どめるべきかを判断しなければならない。

食道癌の気管, 気管支, 肺への浸潤例では, 癌浸潤の 増大の結果, 食道と気道系の間に交通が生じて瘦孔を形 成するものと, 食道癌の気管, 気管支, 肺への浸潤が氮 われる症例に照射療法を施行中，あるいは終了後に突 然, 瘦孔を形成するものとがある。この場合の㾇孔壁は 前者ではもちろん癌組織より成るが，後者の場合には， 癌組織から成るものと, 照射療法によりその部位に癌組

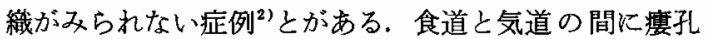
を形成した症例のらち, 非切除例の経過については, 榊 原の報告 ${ }^{23}$ によると，そのほとんぞの症例が瘦孔形成後 短期日のうちに出血または肺炎で死亡している. 教室の 症例も肺炎を併発し，姑息的手術すらでさないまま死亡 
した.これは, 食道癌の気道への浸潤が疑われる症例で は, 食道気道瘦を形成する以前に原発巣を除去すべきこ と, および, 食道気道瘦を形成した症例では合併切除を 行うか，あるいは姑息的手術によって肺炎の併発を防止 しながら膺孔の閉鎖に努力すべきことを示している.

食道癌の気管，気管支浸潤例で湄孔を形成していない 症例に対しては合併切除かまたは切除が行われる. 後者 の場合は漫潤の程度によって癌組織を一応除去できたと 思われる場合と, 明らかに癌組織を残さざるをえなかっ た場合とがある.さらに組織学的検索によって癌組織の 遗残が確認される. 文献的にも, 切除標本の組織学的検 索で, 浸潤部に癌組織がみられなかった症例の報告もあ り, 教室の症例でも1例は痏痕組織のみがみられた。 こ れらは照射療法の効果と考光られる. 饭塚ら $A_{3}$ と判定された食道癌で, 術前治療施行後 $\mathrm{a}_{2}$ 以下と 診断された27例のうち, 気管, 気管支浸潤例と看されて いたものが7例含をれている.すなわら, 手術時 $\mathrm{A}_{3}$ と 判断されて姑息的切除が行われた症例でむ，実際には， 局所的には治瘾切除がなされている可能性が存在しう る. 気管, 気管支浸潤例に対して合併切除が行われる頻

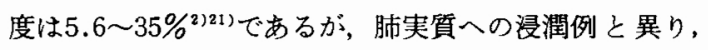
高度の進行例が多いせいか気管, 気管支の合併切除を 行っていない施設も多い. 教室の症例でも気管, 気管支 の合併切除が行われた 2 例はいずれる食道気道㿉形成例 であり，他の 3 例には合併切除は行われなかった。

$a_{3}$ 合併切除例の術後成績について文献的に検討して みると, 掛川 ${ }^{21)}$ の報告によると頝部食道癌では 5 年生存 例もみられることから, 積極的に合併切除を行らのがよ いとしている. 胸部食道癌については, $a_{3}$ 食道癌の切除 例では肺合併症が増加 ${ }^{334)}$ ᄂ, 磯野 ${ }^{4)}$ によると合併切除例 之非合併切除例の 5 生率のカーブはほとんど同様である ので, 合併切除に当ってはその適応を十分に考虑すべき であるとしている. 教室の症例で, 右肺中・下葉切除の 1 例は 4 力月で死亡し, 気管切除の 1 例は直死であっ た. 渡辺らの症例 ${ }^{24}$ では気管部分切除・右下肺部分切除 の 1 例は12日目に死亡しているが，右肺下葉切除の 1 例 は 1 年 9 カ月後生存中である. 教室の症例と比較してみ ると, 気管切除例の経過は似ているが, 肺合併切除の症 例ではりンパ節転移の程度に差があるように思われる。 これは, $a_{3}$ 食道癌切除例の経過はりンパ節転移の程度 が低いもの $\left(a_{3} n_{0}\right)$ が良好であったとの報告 ${ }^{5} や ， a_{3}$ 切 除例の予後を決定する因子として ly あるとの説に一致しており, 気管, 気管支浸潤例に対し
て合併妡除の適応を考觉る場合，Nをたは $\mathrm{n}$ 因子が十 分に考虑さるべきことを示している.ささらに，合併切除 を施行せず，癒着部を削り取った症例で術後 2 年以上生 存した症例の報告 (大橋) むあることを想起し，合併切 除の対象としては $\mathrm{n}$ 因子を十分飞考虑して根治性の期 待できる症例を選ぶべきである.

食道気管または気管支㾇を形成した症例の主な死因は 肺炎と出血である。したがって理論的には瘦孔を含めた 合併切除が理想的であるが，文献上でも，教室の症例を みても合併切除例の予後は現在のところ不良である. 姑 息的沈方法として, permanent esophageal intubation ${ }^{25}$ endoscopic insertion of modified Pezzer Catheter ${ }^{26)}$ どの食道内挿管法 ${ }^{27}$ と, 瘦孔形成部を胎置する方法とが あり，後者はさらに体外人工食道 ${ }^{28}$ と消化管を用いての By-pass 手術とに分けられる. By-pass 手術の目的は, 経口的栄養摂取, ならびに瘦孔からの吸入による肺炎の 防止であるので，残胃からの逆流を防止する目的で工 夫 ${ }^{2933032) か ゙ な さ れ て き た 。 ~}$

食道気管または気管支掼に対する照射療法の意義につ いては議論があるが，照射療法によって食道気管支瘦が 閉鎖した症例の報告（赤倉）むあるので，By-pass 手術 を施行後，照射療法を行うのは有意義と考元る.

肺への浸潤例飞対しては肺部分切除が行われ，時には 肺葉切除が行われる $233(4) 6224331$. 肺の部分切除術の手技 は簡単であるが， $\mathrm{n}_{4}$ 症例がやや多く”，血行性転移を示 すものもあり，予後は必ずしすよくない" では 5 例とも 7 カ月未満で死亡している. 文献上では肺 部分切除例で 5 年以上生存例の報告 ${ }^{2}$ むる. また, 部 分切除を行った肺を組織学的に検索してみると，肺との ものへの漫潤は認められない症例も存在することから， 術前照射療法の必要性と, 積極的に合併切除を行って後 療法を行ら必要性が感じられる.

以上総括すると, 肺浸潤例に対しては積極的に合併切 除を行ない，術前照射療法と術後合併療法を行ならのが よいと思われる。気管, 気管支浸潤例で, 食道気道瘦を形 成していない症例では, $A_{3} ・ N_{0 \sim 1}$ にかぎって合併切除を 考慮し, 合併切除の適応外でも姑息切除を行って原発巣 を除去し，できるかぎりリンパ節を摘出し，術後合併療 法を施行すべきであろう. 気管分岐部の合併切除では, その再建に困難性があるが，Thompson ${ }^{32)}$ は合併切除 後, 気管一気管支端々吻合を行って成功した症例を報告 している. 近年, 気管・気管支形成術 ${ }^{33)}$ 発達してきた ので，その適応を検討すべき時期に至っていると考え 
る. 食道気道瘦を形成した症例は，By-pass 手術が優先 さるべきである.

$$
\text { v. まとめ }
$$

$A_{3}$ 食道癌切除例24例について臨床的ならびに病理学 的に検討し, 気管, 気管支, 肺浸潤例の外科的治療につ いて考察した。

1. $A_{3}$ 食道癌24例のらち $a_{3}$ 症例は16例 $(66.7 \%)$ であり, 気管, 気管支浸潤例は 5 例, 肺浸潤例は 5 例で ある.

2. 気管，気管支浸潤例のうち，食道気道瘻を形成し た 2 例は術前照射療法なしに合併切除を施行したが，4 カ月以内に死亡した，食道気管掼を形成していない症例 に対しては，漫潤部位を削り取るようにして切除が行わ れた. 最長生存例は 7 カ月で,これらの症例にはリンパ 節転移, 肺転移, 骨転移が現れた。

3. 肺漫潤例では， 5 例中 4 例に肺部分切除が行わ れ，1例で㴥りとるようにして剝離された，最長生存 例は 6 カ月で, これらの症例には肺転移，骨転移が現れ た.

4. 気管, 気管支, 肺への浸潤例のうち, 術死 3 例を 除く 7 例中 4 例に術後肺転移がみられたが，4例とも浸 潤側肺への転移であった。

5. 肺浸潤例に比較し, 気管, 気管支浸潤例の方が頙 部リンパ節転移の傾向が大であった.

6. 原発巣では全例が ly (十) であり, INF- $\beta 4$ 例, INF- $\gamma 6$ 例であった. リンパ節転移は $\mathrm{N}_{1} 1$ 例, $\mathrm{N}_{2} 3$ 例, $\mathrm{N}_{3} 1$ 例, $\mathrm{N}_{4} 4$ 例, 不明 1 例であった.

7. 照射例の中には $A_{3}=a_{0 \sim 2}$ の症例があり, 照射に よって浸潤部位の癌組織が消失した症例もある.

8. 肺浸潤例に対しては，肺部分切除が積極的に行わ れる. 気管，気管支浸潤例で食道気道瘦を形成していな い症例では， $A_{3}$ (限局型)・ $\mathrm{N}_{0 \sim 1}$ 症例においてのみ合併 切除が考慮され得る. それ以外の症例では, 食道気道㾇 形成防止の意味からも，浸潤部位をできるだけ含めて切 除が行われ，遣残癌組織には照射を主とした後療法が行 われるべきである.切除不能例および度孔形成例では, まず By-pass 手術を優先し, その後, 根治照射を行うの がよいただし，頚部食道癌 (Ce) 症例は例外である.

9. $\mathrm{A}_{3}$ 食道癌に扑ける気管分岐部の 合併切除ならび にその再建術の適応については，今後さらに厳重な検討 がなされるべきである.

本論文の内容要旨は, 第17回日本癌治療学会総会 (東 京，1979年）で報告した。

\section{文献}

1）食道疾患研究会：臨床・病理食道癌取扱い規 約. 金原出版株式会社, 東京, 1976.

2) 飯塚紀文, 他 : 他荿器に浸潤の及んだ食道癌の 切除手術。 日胸外会誌, $28(4) ： 607-610$, 1980.

3) 木下韍宏, 他 : 他臟器に漫潤の及んだ食道癌の 外科的治㙩。日胸外会誌, 28 (4)：610一612, 1980.

4) 磯野可一：他㼨器に浸潤の及んだ食道癌の外科 的治療。日胸外会誌, 28(4)：612-615，1980.

5) 森昌造, 他 : 他䑏器に浸潤の及んだ食道癌の 外科的治療. 日胸外会誌, 28 (4)：615-617, 1980.

6) 秋山 洋: 他臟器に浸潤の及んだ食道癌の外科 的治療。 日胸外会誌, 28(4)：605-607, 1980 .

7) 忽那将愛 : 日本人のリンバ系解剖学, 金原出版 株式会社, 東京, 1968 .

8）森堅志：気道及び食道のリンパ管。気食会 報, 19:85-98, 1968.

9) Nagaishi, Ch.: Functional Anatomy and Histology of the Lung. Igaku Shoin LTD., Tokyo, 1972.

10) McCort, J.J.: Radiographic Identification of lymphnode metastases from carcinoma of the esophagus. Radiology, 59: 694-711, 1952.

11) Sweet, R.H.: The results of radical surgical extirpation in the treatment of carcinoma of the esophagus and cardia, with five year survival statistics. S.G.O., 94: 46-52, 1952.

12）吕俊彦：術前照射を行った食道癌のリンパ節 転移に関する臨床病理学的研究。日外会誌, 71 (7) : 835-847, 1970.

13）立花孝史：胸部食道癌の淋巴節転移に関する臨 床的並び (7) : 891-903, 1971.

14）佐藤 博：胸部食道癌のリンバ節転移に関する $2 \sim 3$ の検討. 胸部外科, $19(10): 682-686$, 1966.

15）川口正樹：食道癌の臨床病理学的研究. とくに リンバ節転移を中心に, 日胸外会誌, 21 (6) : 575-586, 1973.

16）秋山洋, 他：食道癌のリンパ節転移および徳 性度類型について。外科, 36 (13) : 14351445, 1974.

17）富田正雄, 他：胸部食道癌治療の困難性につい て。特に非手術例の検討とリンパ節転移につい て. 外科診療, $15(3)$ ： $341-345,1973$.

18）井手博子, 他：胸部食道癌のリンパ節転移。手 術, 18 (12) : 1355-1364， 1974.

19）三戸康郎，他：胸部食道癌の䅡部リンパ節（左 右下内深頚部）転移の実態とその対策，ことに 上粉隔りンパ節転移との関連において，日胸外 
会誌, 28 (2)：241-247, 1980.

20) 平野雅士, 他: 胸部食道癌の澒部リンパ節転移 の診断と治療，Lipiodol Bleomycin によろ甲状 腺経由頝部リンパ節造影法の 経験。癌の臨床, 24 (4) : 283-288, 1978.

21）垪川暉夫，他：他贜器に浸潤が及んだ食道癌の 外科的療法。頚部食道癌を中心に，日胸外会 誌, 28 (4) : 603-605, 1980.

22) Garlock, J.H. and Klein, S.H.: The surgical treatment of carcinoma of the esophagus and cardia. Annals of Surgery, 139(1): 19-34, 1980.

23）榊原宣, 他：食道癌における食道気道瘦。外 科診療, 12 (11) : 1409-1414, 1970.

24) 渡辺宽, 他：食道癌に対する合併切除術。そ の必要性と問題点. 癌の臨床, 26 (2)：136一 145, 1980.

25) Judd, D.R. and Codd, J.: Palliation for malignant esophagotracheal fistula. J. Thoracic Cardiovas. Surg., 54(5): 751-755, 1967.

26) Kovarik, J.L.: Palliative treatment of a bronchoesophageal fistula. J. Thoracic Car- diovas. Surg., 46(2): 252-255, 1963.

27) 中山恒明, 遠藤光夫: 食道癁の補助療法. 食道 内㨉管法について。臨床外科, $21: 39-48$, 1966.

28) 竹林 淳, 他: 切除不能の食道噴門癌に対する 姑息的療法. 手術, 29(7) : 767一772, 1972 .

29) Papaioannou, A.N.: A simple operation for the palliative treatment of tracheoesophageal fistula due to cancer. J. Thoracic and Cardiovas. Surg., 49(5): 881-885, 1965.

30）秋山洋, 他：食道悪性腫瘍に上る気管食道掼 の姑息的手術療法. 特に食道眙置と噴門瘦造設 について。手術, 23 (4) : 418-425, 1969.

31）渡辺寛, 他: 切除適応限界と思われる食道癌 症例の手術経験。日胸外会誌, 20 (12):925934, 1972.

32) Thompson, D.T.: Lower tracheal and carinal resection associated with subtotal oesophagectomy for carcinoma of oesophagus involving trachea. Thorax, 28: 257-260, 1973.

33) 中村 讓, 他 : 気管・気管支形成術之成績。日 外会誌, 80 (11)：1215-1219，1979. 